\title{
CENTRAL PLACE FORAGING CHARACTERISTICS OF BEAVERS ( CASTOR CANADENSIS) AND HABITAT MODELING IN GRAND TETON NATIONAL PARK
}

\author{
WILLIAM J. GRIBB $\uparrow$ HENRY HARLOW $\uparrow$ UNIVERSITY OF WYOMING $\uparrow$ LARAMIE
}

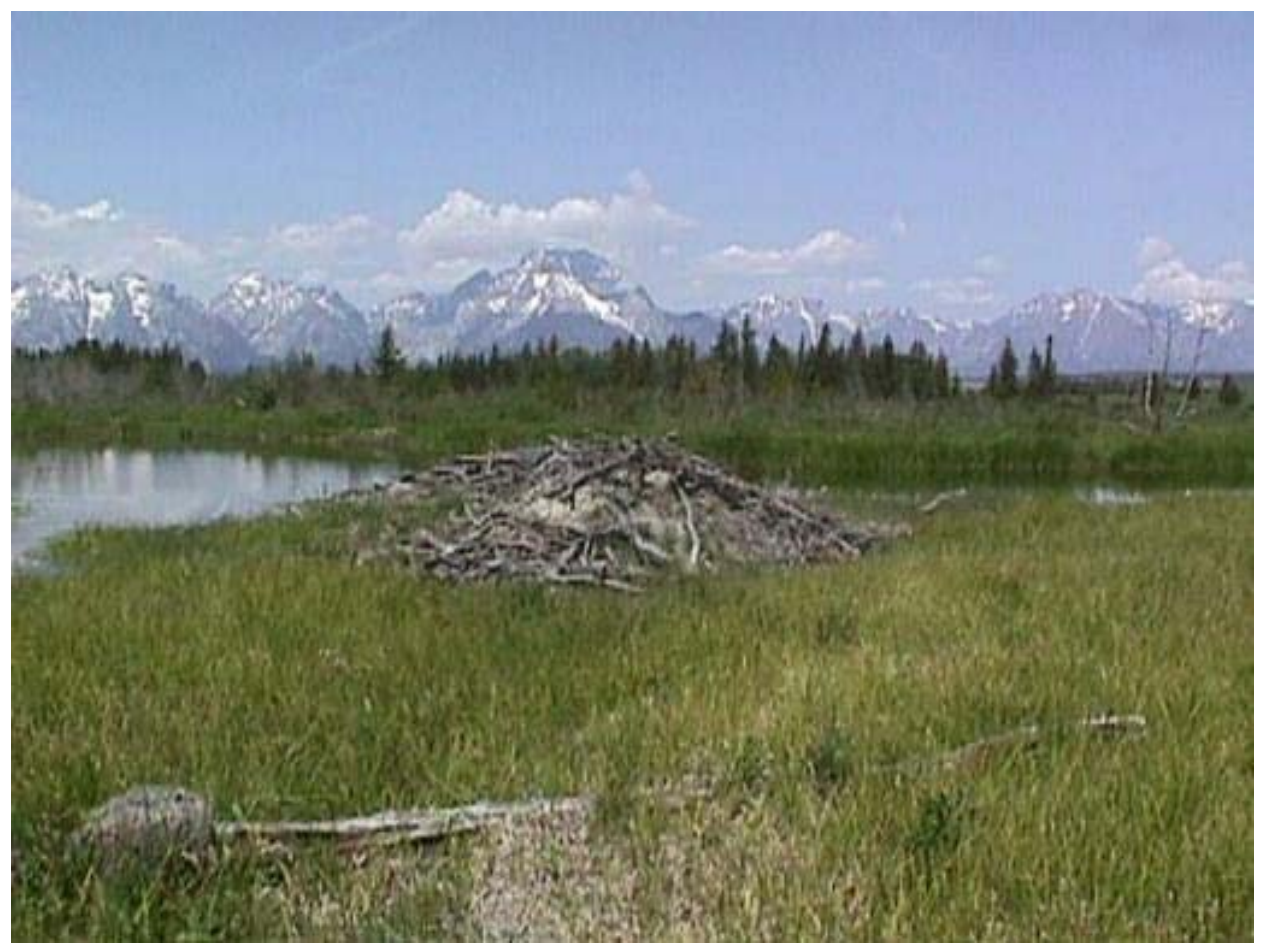

\section{$\uparrow \quad$ JUSTIFCIATION AND SCOPE}

A significant role of the National Park Service in the United States is the preservation of pristine landscapes. The natural landscape offers the visitor the opportunity to enjoy the wonders of nature and its processes to create beautiful vistas, soaring mountains, and the interplay of vegetation communities. The visitor to the park can be a passive recreationist and observe the landscape or be an active recreationist and experience the landscape through hiking, biking, mountain climbing and a range of other activities. The key linkage between the active and passive recreationist is the landscape that they are experiencing, in one perspective or the other. Any disruption of that natural landscape diminishes the experience. Unfortunately, the perception of the disruption varies with each individual. The trail to get to a scenic vista can be overlooked by some observers, while others believe it is an example of the devastation of human impact.

Figure 1 is an image of the impact of beavers near Spread Creek. To some observers it is nature's natural landscape, to others the beaver is as devastating 
to the landscape as a lumber jack is to the forest. The alterations to the landscape made by the beaver are far reaching including not only the cutting down of whole trees for the construction of lodges, but the damming of streams and the creation of ponds and subsequent wetlands. However they are perceived, the importance of beavers to the ecosystem has been identified by a number of authors (Naiman et al. 1986, Naiman et al. 1988, Muller-Schwarze and Sun 2003, and Wright and Jones 2006).

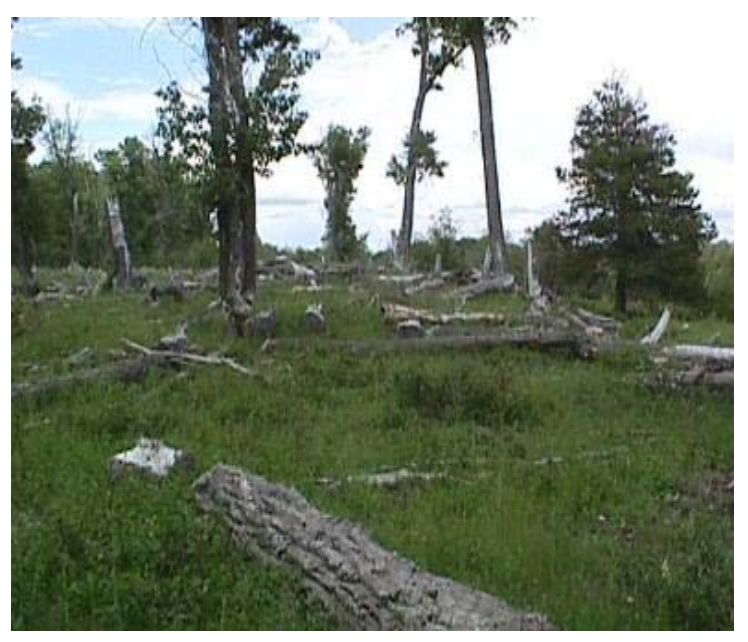

Figure 1. Beaver tree cuttings near Spread Creek.

Research on beavers has a long and varied past with one of the first major works describing and analysing beaver locations, imprint on the landscape, movements, and habitats by Lewis Morgan in 1868. As time has progressed, more in-depth analyses have been completed on a number of aspects of beaver ecology. Two major types of beaver studies focus on their movement and foraging habits. The area of daily and seasonal movements delineates the beaver's territory, which has both a spatial and social component. The size and densities of the territories provide knowledge of the distribution and population of beavers in an area. The social dynamics of the territories can have two dimensions, the intra-colony interactions of parents to their off-spring and sibling relations, and the interaction between colonies that make-up the territories. This research will focus on the spatial aspects of beaver territorial foraging and the determination of beaver movements as they relate to foraging along the Snake River.

The overall problem addressed in this research is to determine the spatial extent and patterns of beaver foraging over the course of a foraging cycle-six to nine months. By using micro-GPS technology, beaver movements can be captured at a high spatial and time resolution to examine the route, forage-time, and spatial extent of their eating and construction activities. The micro-GPS technology has the ability to collect up to 60,000 locations providing species coordinates and timeline, thus providing accurate information of their movements and time sequencing.

This research is a continuation of the research proposal submitted to the UW-NPS Research Station last year, 2011-2012. The following are our continuing research objectives:

1. Map riparian habitat along the Snake River corridor, focusing on side-channels used by beavers.

2. Document beaver activity and habitat utilization by tracking their movement to and from their lodge, along a particular sidechannel, and more broadly within the riverine environment using micro-GPS units.

As mentioned previously, the spatial characteristics of beaver foraging are the main thrust of this project. Beavers that have built lodges, either along a bank or in a pond/lake, radiate out from that location to forage, and thus are considered central place foragers (Jenkins 1980). Studies have found that because of the characteristics of their prey species, beaver foraging changes with distance from water (Jenkins 1980, Belovsky 1984, McGinley and Whitham 1985, Gallant et al. 2004, and Raffel et al. 2009). Generally, the foraged plant species increase in size with distance from water, either a lake or pond. Raffel et al. (2009) along with Pinkowski (1983) and Gallant et al. (2004) found that not only were there size differences with distance, but also species selectivity. Thus, the overall foraging by beavers has an impact on the vegetation density and composition (Donkor and Fryxell 1999, Barnes and Mallik 2001). These changes can then have an overall impact on the ecosystem if sustained over a long period of time.

A typical central place study will locate the lodge that is the home of the beaver colony and survey vegetation species from that location noting type and foraging activity. In the study by Raffel et al. (2009) they completed a survey of beaver activity around the lake and identified eight foraging sites with beaver cuts less than 2 years old. The research team delineated the sites by the extent of foraging and then recorded information on all of the tree species $(>1 \mathrm{~cm}$ in diameter) within the foraging area, distance from shore, cut status and stem/trunk diameter. Their analysis consisted of modelling the preferred foraged species and relating this to size, distance from shore and distance from the lodge. Overall, this aspect of the 
Grand Teton NP beaver foraging has been completed for several select sites (Gribb and Harlow 2011).

This research has two major distinctions from the cited research. First, there has only been one central place foraging study along a western US river system. McGinley and Whitham (1985) examined the central place foraging of beavers along the San Juan River, UT. They specifically focused on cottonwoods (Populus fremontii) and only in one select location. Breck et al. (2001) were not specifically examining central place foraging, but they did study beaver home range along the Yampa and Green Rivers.

The focus of this beaver research was originally designed to address movements along the Snake River, addressing beaver foraging along a western river, an aspect that has not been fully examined. Second, this study captured beaver movement with the micro-GPS unit, a process that has never been attempted. Not only were the foraging locational patterns recorded, but also foraging times. Fryxell and Doucet (1993) recorded this same type of information with beavers in an enclosure using visual observations, but they provided pre-cut tree stems and embedded them into the soil to determine foraging selection, times and distances. The current study recorded real foraging times and movement coordinates in a natural environment.

\section{$\uparrow \quad$ SIGNIFICANCE}

This project has three points of significance. First, this is a technological innovation project attaching a micro-GPS unit to beavers. This had not been attempted before, and the process and procedures were recorded to provide a framework upon which to build additional research in this technique. In the work of Raffel et al. (2009) the researchers GPS'd the activity areas of the beaver and did their calculations all after the fact. Several studies have fixed a radio telemetry unit to the tail of the beaver and systematically monitored their locations using telemetry (Rothmeyer et al. 2002, McNew and Woolf 2005, and Bloomquist and Nielsen 2010). The shortcoming of this technique is that the location and movements between telemetric readings is unknown, the only location information collected is at the times and days selected by the researchers, thus a biased sampling of activities and movement were collected. The micro-GPS unit has the capability to capture a signal at a set time interval, every 5 minutes, thus allowing a systematic sampling of beaver locations (www.telemetrysolutions.com) over the entire research period. In this case, the research period was only from May 26-June 2, 2013. One known shortcoming of this system is that GPS signals generally do not penetrate water to a depth of more than $20 \mathrm{~cm}$. In a sample test with a hand-held GPS, locations underwater were collected to a depth of $1 \mathrm{~m}$ (Gribb, unpublished 2011). However, the hand-held GPS unit had a much larger antenna than the unit attached to our test beaver. The unit used in this study was only $52 \mathrm{~mm}$ (w) $\times 78 \mathrm{~mm}$ (l) $\times 28 \mathrm{~mm}$ (h). The signal was lost as the beaver entered/exited the lodge or swam in deeper water. In addition, the signal was lost while the beaver was in the lodge.

The second point of significance for this study is that it provides a detailed record of the extent of beaver foraging, though for only a short time period (May 26-31) in the Spread Creek meadow pond complex in Grand Teton NP. The resolution of the location and movement data provides the detail that is needed to determine home range and colony territory. This study recorded the movement of the beaver in a pond area that encompasses approximately $11 \mathrm{ha}$ with a complex of 20 ponds, with 10 greater than 0.03 ha and 10 less than 0.03 ha. The captured location data allows the researchers to calculate the distances travelled, frequency of pond use, the frequency of water way use, and the proportion of time on each pond. This type of information has not been recorded for any western ponds, a dominant feature for beaver habitats in the mountainous western U.S.

The third point of significance is the building of a beaver habitat model that incorporates a range of data for a riverine habitat. Most models utilize either a pond site/situation (Gallant et al. 2004) or a broad area approach (Slough and Sadlier 1977, Allen 1983, Howard and Larson 1985, Beier and Barrett 1987, South et al. 2000, Beck and Staley 2005, Maringer and Slotta-Bachmayr 2006, Cox and Nelson 2006, Frantisek and Kostkan 2009, and Bird et al. 2013). This model is based on a combination of remote sensed data of vegetation with digital data on topography, soils, and stream reach delineations. The Snake River has two significant components, the portion above the Jackson Lake Dam and the portion below the Jackson Lake Dam. The portion above the dam is unrestricted and natural, whereas the portion below the dam is significantly impacted by releases of water held by the Jackson Lake Dam. The examination of beaver habitat along a river in the western United States has been limited (Slough and Sadleir 1977, Howard and Larson 1985, Breck et al. 2003, Bryan et al. 2013). This habitat model relies on the stream density, vegetation, soils and slope factors to determine the potential habitat along the Snake River stream reaches. 


\section{METHODS}

The general strategy of the central place foraging investigation is to characterize beaver riparian ecology by an inventory of the foraged vegetation and the monitoring of an individual beaver using a pair of tracking methods, and to integrate these two sources of information to provide insight on physical factors influencing beaver behavior patterns. Our study involved a combination of geospatial data analysis and field work, and each of these components is described in the following sections. The project initially proposed to examine three specific beaver habitats: a segment of the Snake River adjacent to the Bar BC Ranch with backwater tributaries; a segment of the Snake River $5 \mathrm{~km}$ downstream from the Flagg Ranch bridge without a backwater tributary; and a beaver pond sequence along Spread Creek, $1 \mathrm{~km}$ east of US26/US98/US191. Each of these locations had active beaver lodges and displayed active foraging.

To understand beaver habitat utilization and movements, a systematic method of collecting beaver locational data was needed. The first task is to locate, live-trap and attach a micro-GPS unit on a beaver. Because this is a pilot project to test the use of a microGPS unit, one beaver would be captured at each of the three pilot locations, fitted with the device and released. To make recovery of the GPS unit easier and to test the procedure for capturing, attaching the unit and collecting data afterwards, a beaver was trapped first at the Spread Creek ponds complex. Trapping of the beaver was accomplished by a team composed of experienced wildlife handlers, Dr. H. Harlow (UW Dept. of Zoology and Physiology) and Drew Reed (formerly Wyoming Wetland Society) on May 26, 2013. To facilitate handling and reduce the capture trauma, the beaver was anesthetized using the process described by McNew et al. (2007). A measured dose of ketamine hydrochloride and xylazine hydrochloride was administered with appropriate lag time for recovery before release. All UW, AMS, NPS, and USDA wildlife handling guideline procedures were followed (Appendix A, UW IACUC permit). A portion of a small GPS device $(80 \mathrm{~mm} \times 10 \mathrm{~mm} \times 10 \mathrm{~mm})$ was glued to the beaver tail and another part of the unit was belted to the base of the beaver tail. This would allow flexibility of tail movement and the aerodynamic design of the GPS would minimize the possibility of the unit being caught-up on vegetation and underwater debris. In addition, a radio-telemetry device as a component of the micro-GPS was activated at the same time as the GPS unit.

To accomplish our research objectives, the micro-GPS unit attached to an adult beaver can possibly collect the coordinates of their movements for six months. Because the GPS uses a set time interval between location recordings (every 5 minutes upon connecting to the GPS-satellite network) detailed movements can be documented. Finally, the radiotelemetry antenna assisted in locating the beaver to download the GPS data, allow for re-capture and removal of the micro-GPS. According to Bryan Bedrosian, Beringia South, data can optimally be downloaded within a radius of $400 \mathrm{~m}$ from the GPS unit. However, if the beaver has moved from its lodge it will be critical to locate the beaver and retrieve the data from the micro-GPS, thus a vhf radio telemetry unit is built into the micro-GPS unit. All necessary procedures were followed to ensure that the recording devices and study area were not disturbed nor impact recreationists. The pilot study areas were selected because of their locations away from river recreationists- rafters and fishermen and the general public.

To map the terrain and riverine characteristics of the Snake River required combining field data, remote sensed data and digital environmental data. Objective \#2 is to examine and analyze the interrelationships between these different data sets to produce the appropriate maps and a new, more robust beaver potential habitat model. The field and remote sensed data have been described previously, the environmental factors were derived from GTNP, USGS, and UW WyGISC data sets on topography, hydrology, vegetation, soils, and geology. The integration of these different types of data sets provided a model that is multi-dimensional and dynamic, parameters that Shenk and Franklin (2001) thought critical to any natural resource management modeling. The remote sensing and river morphological measurements were the main components of the habitat model. This integration of data sets incorporated the use of multi-dimensional spatial analysis to determine the statistical significance of the different field measurements, environmental factors, and remote sensed imagery in the construction of the new habitat model.

\section{$\uparrow \quad$ RESULTS}

Mapping the Snake River corridor for beaver habitat involved compiling the appropriate spatial datasets from a variety of sources. The appropriate datasets for identifying beaver habitat can be categorized into five major components as identified by a number of researchers (Slough and Sadlier 1977, Allen 1983, Howard and Larson 1985, Beier and Barrett 1987, South et al. 2000, Beck and Staley 2005, 
Maringer and Slotta-Bachmayr 2006, Cox and Nelson 2006, Frantisek and Kostkan 2009, and Bird et al. 2013): water, landscape, vegetation, soils, and anthropogenic factors. The water component details the characteristics of the water system: water flow, stream order, stream characteristics (width, depth, stream reach length), stream reach, stream gradient, bank height, floodplain width, wetlands, pond size, braiding, and sinuosity. The landscape factors generally relate to topography, slope and orientation. Vegetation has a number of different factors that are examined including species, communities, species/communities a set distance from water, tree and shrub density, tree diameter breast height, tree and shrub canopy cover, shrub height, shrub stem size, and browse/cutting evidence. Soils information is generally texture and depth, especially a set distance from water. Anthropogenic factors are distance to residential/commercial development, river engineering (dams, levees, channelization, and bank stabilization), road density, and farming.

This project did not utilize all of the factors, but did employ parts of four of the five components. The water component consisted of the main hydrology of Grand Teton National Park at the HUC-12-level and the identification of all lakes and ponds (over $0.25 \mathrm{ha}$ ). Another aspect of the water component entailed using the river reaches delineated by Nelson (2007) and modifying their boundaries to correspond with the Snake River floodplain. The river reaches were used as the main spatial units for analysis because of the geomorphic characteristics they portray. The vegetation component consisted of the spatial distribution of the specific species communities, in this case willows (Salix spp.) and cottonwoods/aspens (Populus spp.), the two main species consumed by beavers in Grand Teton National Park (Collins 1977). Soil texture is a key for beavers building bank dens along the Snake River channel, but not as important for bank lodges in the backwater tributaries. Finally, the anthropogenic factor that is the most dominant in Grand Teton National Park is the Jackson Lake dam. To accommodate the influence of the dam, the Snake River is divided into two portions, the Upper Snake River $(15.9 \mathrm{~km})$ and the Lower Snake River $(43.4 \mathrm{~km})$ with the dam as the separator. The other anthropogenic factors are not considered in the modeling.
General descriptors of the Snake River corridor provide a needed background for the project overall. The topography and slope of the Snake River is not as dramatic as most streams. The northern reach of the Snake River at the southern border of Yellowstone National Park has an elevation of $2091 \mathrm{~m}$ and this flows into Jackson Lake with a normal elevation of $2064.6 \mathrm{~m}$, thus the Upper Snake River gradient over this $16.2-\mathrm{km}$ stretch is only $0.17 \%$. The southern reach from Jackson Lake Dam (2064.6 m) to Moose $(1969 \mathrm{~m})$ is $42.9 \mathrm{~km}$ and has a gradient of $0.23 \%$. The low gradient provides an environment in which the Snake River has the potential to create significant braided streams with a large sinuosity index.

The Snake River was divided into 27 reaches, 7 reaches on the Upper Snake River above Jackson Lake and 20 reaches from Jackson Lake dam to Moose (Nelson 2007). Defining aspects of each reach related to the geomorphic characteristics of the stream channel: sinuosity, braiding, confluence, width/depth, floodplain and gradient. Figure 2 illustrates the delineation of the reaches. The average reach is approximately $121.2 \mathrm{ha}$, however, there is a significant difference between the area of the Upper Snake River reach and the Lower Snake River reach, 35.5 ha versus 151.2 ha, respectively. The Upper Snake River flows through a narrow canyon for almost one-half of its distance, whereas the Lower Snake River spreads out across the Snake River valley below the dam. Both sections of the river, however, are similar in average reach stream length $2296.9 \mathrm{~m}$ and gradient $0.20 \%$.

Vegetation along the Snake River was identified and delineated by the Grand Teton National Park using 2005 NAP photography at a resolution of $1 \mathrm{~m}$. This data was up-dated using 2012 NAP photography at the same resolution. The updates were generally associated with the meandering of the Snake River and the increase/decrease or elimination of sand bars and movement of vegetation along cutbanks. Two major categories of vegetation were distinguished, communities of Salix spp. and Populus spp. These two major communities were formed by combining the following vegetation classes: Salix spp includes Salix spp. shrubland; Populus spp. includes Populus tremulides forest, mixed conifer-Populus spp., Populus angustifolia-Populus balsamifer riparian forest, and Populus tremuliodes woodland regenerated. Table 1 provides an overview of the proportion of each major beaver habitat vegetation community by reach. 
Table 1. Vegetation communities by reach.

\begin{tabular}{|c|c|c|c|c|c|c|c|}
\hline Reach & Area(ha) & $\begin{array}{l}\text { Salix } \\
\text { spp.(ha) }\end{array}$ & \%Reach & $\begin{array}{c}\% \text { SR } \\
\text { Total } \\
\end{array}$ & $\begin{array}{l}\text { Populus } \\
\text { spp.(ha) }\end{array}$ & \%Reach & $\begin{array}{c}\% \text { SR } \\
\text { Total } \\
\end{array}$ \\
\hline UpperSnake_Reach1 & 17.02 & 1.63 & 9.59 & 0.74 & 0.00 & 0.00 & 0.00 \\
\hline UpperSnake_Reach2 & 9.18 & 0.00 & 0.00 & 0.00 & 0.00 & 0.00 & 0.00 \\
\hline UpperSnake_Reach3 & 11.72 & 0.57 & 4.88 & 0.26 & 0.00 & 0.00 & 0.00 \\
\hline UpperSnake_Reach4 & 4.86 & 0.62 & 12.72 & 0.28 & 0.00 & 0.00 & 0.00 \\
\hline UpperSnake_Reach5 & 59.74 & 17.22 & 28.83 & 7.78 & 0.00 & 0.00 & 0.00 \\
\hline UpperSnake_Reach6 & 159.08 & 73.67 & 46.31 & 33.30 & 4.22 & 2.65 & 100.00 \\
\hline UpperSnake_Reach7 & 254.89 & 127.53 & 50.03 & 57.64 & 0.00 & 0.00 & 0.00 \\
\hline Upper Snake Total & 516.48 & 221.24 & & 42.84 & 4.22 & & 0.82 \\
\hline LowerSnake_Reach1 & 85.81 & 27.39 & 31.92 & 6.44 & 4.42 & 5.15 & 0.48 \\
\hline LowerSnake_Reach2 & 72.23 & 7.78 & 10.78 & 1.83 & 4.45 & 6.16 & 0.48 \\
\hline LowerSnake_Reach3 & 131.75 & 23.99 & 18.21 & 5.64 & 5.96 & 4.52 & 0.64 \\
\hline LowerSnake_Reach4 & 63.31 & 6.35 & 10.02 & 1.49 & 0.00 & 0.00 & 0.00 \\
\hline LowerSnake_Reach5 & 10.68 & 1.95 & 18.23 & 0.46 & 0.40 & 3.70 & 0.04 \\
\hline LowerSnake_Reach6 & 14.62 & 0.46 & 3.15 & 0.11 & 0.66 & 4.52 & 0.07 \\
\hline LowerSnake_Reach7 & 9.23 & 1.39 & 15.03 & 0.33 & 0.66 & 7.16 & 0.07 \\
\hline LowerSnake_Reach 8 & 109.25 & 15.08 & 13.80 & 3.54 & 0.79 & 0.72 & 0.08 \\
\hline LowerSnake_Reach9 & 3.91 & 0.00 & 0.00 & 0.00 & 0.00 & 0.00 & 0.00 \\
\hline LowerSnake_Reach10 & 118.53 & 21.40 & 18.05 & 5.03 & 5.00 & 4.22 & 0.54 \\
\hline LowerSnake_Reach11 & 59.69 & 29.68 & 49.72 & 6.97 & 10.18 & 17.06 & 1.09 \\
\hline LowerSnake_Reach12 & 24.35 & 6.57 & 26.99 & 1.54 & 15.01 & 61.65 & 1.61 \\
\hline LowerSnake_Reach13 & 169.67 & 59.56 & 35.10 & 14.00 & 49.87 & 29.39 & 5.36 \\
\hline LowerSnake_Reach14 & 99.70 & 3.31 & 3.32 & 0.78 & 64.20 & 64.39 & 6.90 \\
\hline LowerSnake_Reach 15 & 788.91 & 77.37 & 9.81 & 18.18 & 217.59 & 27.58 & 23.37 \\
\hline LowerSnake_Reach16 & 118.69 & 2.51 & 2.12 & 0.59 & 50.41 & 42.48 & 5.41 \\
\hline LowerSnake_Reach17 & 857.76 & 86.14 & 10.04 & 20.24 & 367.87 & 42.89 & 39.51 \\
\hline LowerSnake_Reach18 & 89.67 & 21.70 & 24.20 & 5.10 & 37.53 & 41.85 & 4.03 \\
\hline LowerSnake_Reach19 & 29.38 & 10.11 & 34.39 & 2.37 & 10.27 & 34.94 & 1.10 \\
\hline LowerSnake_Reach 20 & 166.56 & 22.82 & 13.70 & 5.36 & 85.81 & 51.52 & 9.22 \\
\hline Lower Snake Total & 3023.70 & 425.55 & & 14.07 & 931.06 & & 30.79 \\
\hline Grand Teton NP Total & 3540.18 & 646.79 & & 18.27 & 935.28 & & 26.42 \\
\hline
\end{tabular}



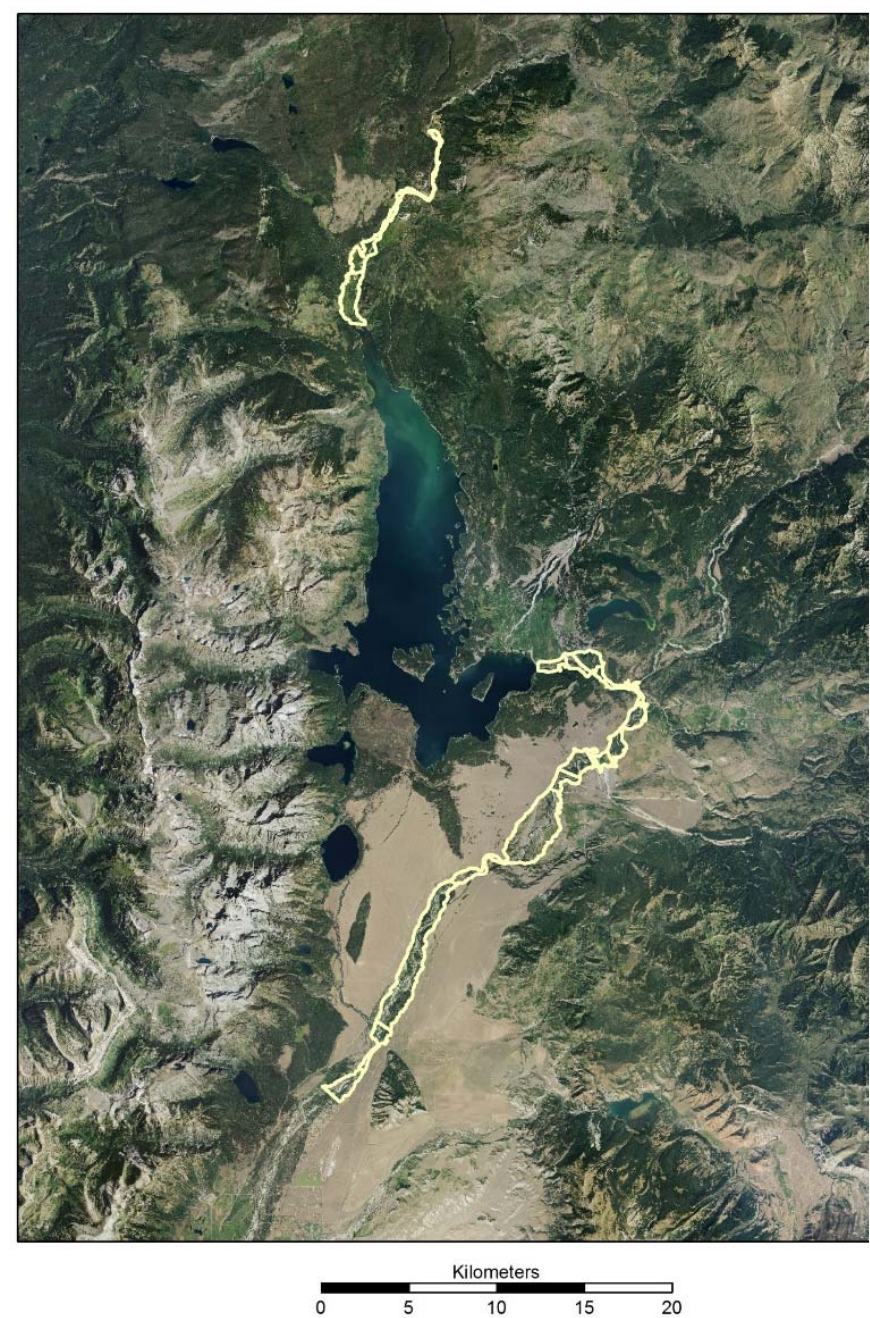

Figure 2. Upper and lower Snake River reaches.

The soil component of the model was derived from the U.S. Soil Service Soil Survey of Teton County, Wyoming Grand Teton National Park Area and the digital SSURGO data files of the Natural Resources Conservation Service. Along the Snake River below the Jackson Lake Dam, the dominant soils are the Tetonville gravelly loam, Tetonville complex, Tetonville-Riverwash complex and assorted TetoniaLantonia and Taglake-Sebud associations. As the Snake River meanders through the valley there are cyclical occurrences of sandbars and cutbanks, braided stream and straight bank stream. Intermittently the Snake River cuts into the older stream terraces and creates a high bank, steep slope gravel, cobble and sand embankment.

The overall result of the multi-factored analysis is a map of potential beaver habitat along both portions of the Snake River. The potential beaver habitat accounts for only a small percentage of the
Snake River corridor, limited by the vegetation communities and the extensive braiding in several river reaches (Figures 2 and 3). Major portions of the river's bank conditions are not suitable for bank dens or bank lodges because of the high percentage of cobbles, gravel and sand. In addition, the alternating sand bars and cut banks do not offer areas suitable for dens or lodges.

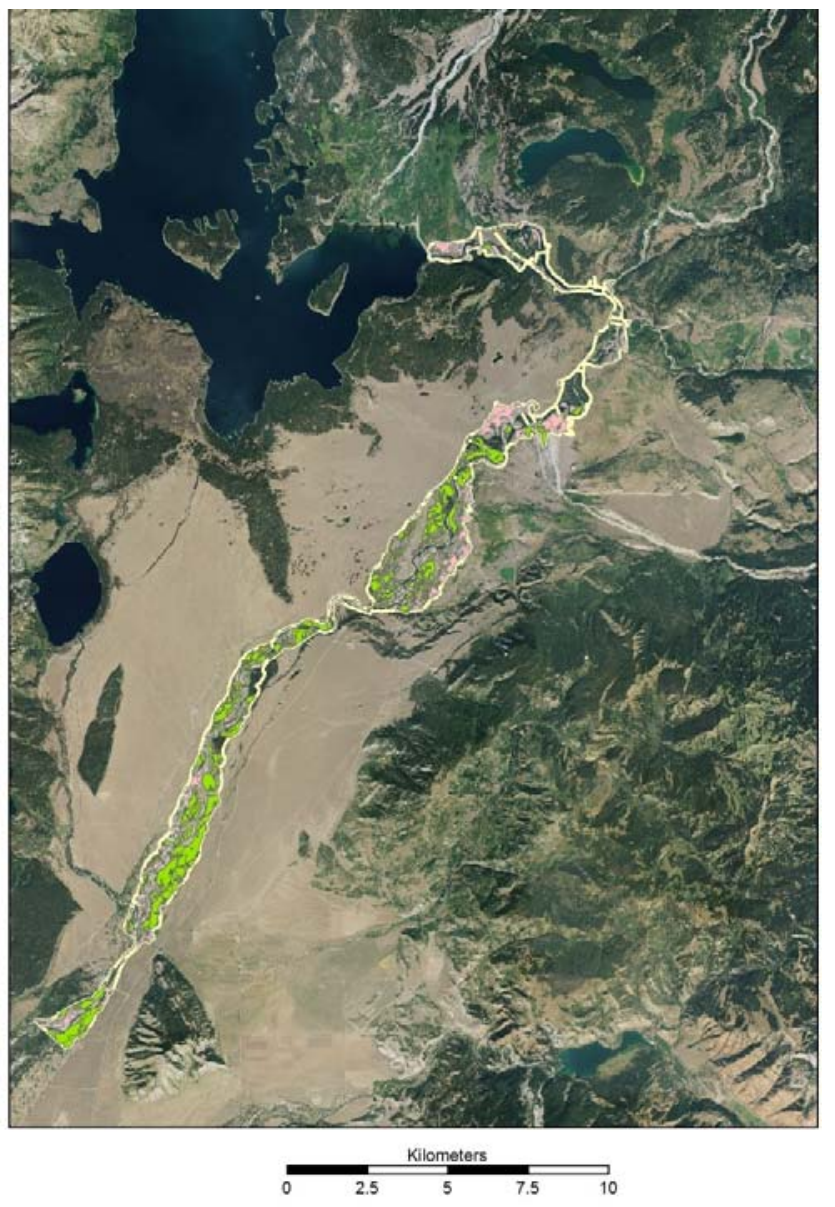

Figure 3. Lower Snake River potential beaver habitat.

The second objective of this project was concerned with documenting beaver activity areas, central place foraging. The initial intent was to attach a micro-GPS unit to a beaver and track its movements over six months. Three beaver activity areas were selected to conduct this original research: two locations on the Snake River (one on the Upper Snake River and one on the Lower Snake River) and one site in the Spread Creek pond complex. To test the procedure for live capturing, anesthetizing, attaching the GPS and downloading the location data, the Spread Creek pond complex was selected for ease of access and limited range of the beaver. On May $26^{\text {th }}$ the unit was attached to a $21.8 \mathrm{~kg}$ beaver. The unit stayed attached until May $31^{\text {st }}$, with the collection of 128 UTM coordinate points. 
Table 2. Descriptive statistics of GPS positions -- distance to lodge by day.

\begin{tabular}{|c|c|c|c|c|c|c|}
\hline \multicolumn{2}{|c|}{ Overall Description } & May $26-27$ & May 27-28 & May 28-29 & May 29-30 & May 30-31 \\
\hline Mean & 113.12 & 57.20 & 154.14 & 122.87 & 148.16 & 137.92 \\
\hline Standard Error & 5.82 & 1.57 & 18.79 & 13.25 & 7.41 & 13.47 \\
\hline Median & 100.81 & 57.68 & 135.88 & 132.07 & 145.59 & 146.54 \\
\hline Standard Deviation & 65.84 & 10.28 & 88.11 & 57.75 & 34.74 & 63.16 \\
\hline Coefficient of Variation & 58.20 & 17.97 & 57.16 & 47.00 & 23.45 & 45.79 \\
\hline Kurtosis & 0.57 & 0.40 & -0.48 & -0.87 & 1.09 & -0.26 \\
\hline Skewness & 0.93 & 0.48 & 0.70 & 0.13 & -0.18 & -0.32 \\
\hline Range & 311.52 & 47.26 & 287.84 & 193.31 & 155.55 & 221.22 \\
\hline Minimum & 15.36 & 39.35 & 39.04 & 37.87 & 64.55 & 15.36 \\
\hline Maximum & 326.88 & 86.61 & 326.88 & 231.17 & 220.11 & 236.58 \\
\hline Count & 128.00 & 43.00 & 22.00 & 19.00 & 22.00 & 22.00 \\
\hline
\end{tabular}

Table 3. Ring-sector analysis, Spread Creek Pond complex.

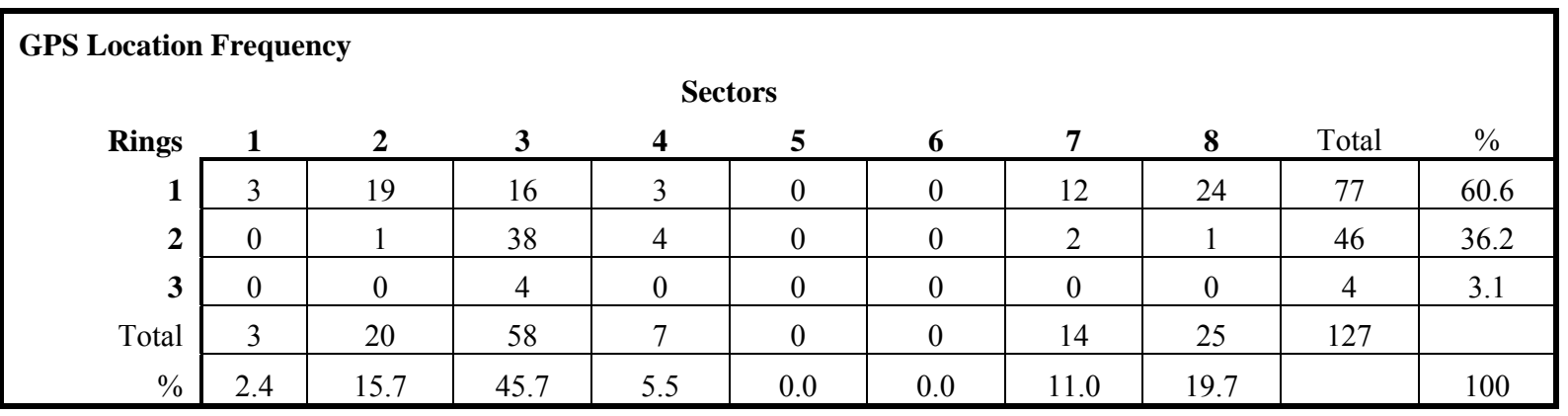

Figure 4 displays the distribution of the recorded positions, with an overall central foraging area of 11 ha. There is a complex of 20 ponds with $10>$ 0.03 ha and $10<0.03$ ha. Table 2 provides a listing of the descriptive statistics for each day of activity and the overall descriptive statistics. May 26-27 the beaver did not venture far from the lodge, averaging only 57.2 meters from the lodge. However, from May $28^{\text {th }}$ until May $31^{\text {st }}$ the average distances increased to $122-154 \mathrm{~m}$ with an average coefficient of variation of $41.42 \%$. On May $31^{\text {st }}$ at $05: 30$ am the micro-GPS unit became detached from the beaver, both the glue and the strap failed. The micro-GPS unit was retrieved using the VHF signal.

Descriptive spatial statistics portray the distribution of foraging by the tagged beaver. Using ring-sector analysis it is possible to analyze the spatial distribution of foraging at the Spread Creek Pond complex. Table 3 displays the number of point locations per ring/sector from the lodge, with element (Ring-2, Sector-3) containing 38 points $(29.9 \%)$ of the 127 point total. This element has a high density of willows and easy access from one pond to another (Figure 5). A constraint in foraging is a high embankment $(5 \mathrm{~m})$ approximately $100 \mathrm{~m}$ from the lodge and oriented NW-SE. This is evident by the fact that over $80 \%$ of the points are in sectors 8,2 and 3 . This embankment separates the meadow-pond complex from the surrounding outwash plain.

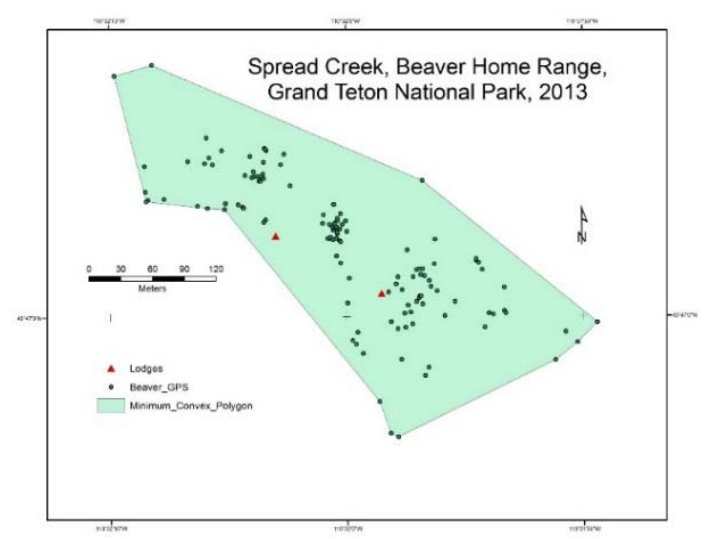

Figure 4. GPS positions and home range, Spread Creek pond complex. 


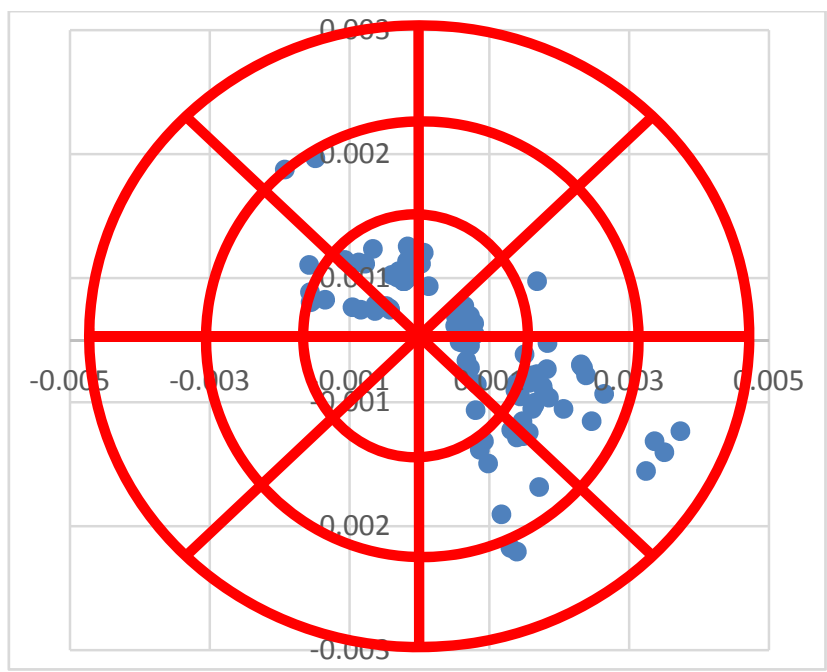

Figure 5. GPS positions, ring-sector analysis, Spread Creek pond complex (scale: $0.001=115 \mathrm{~m}$ ).

On June 26, 2013 another attempt was successful in live-trapping a second beaver $(23.2 \mathrm{~kg})$ and attaching a micro-GPS unit. A modification was made to the strap to strengthen its attachment to the GPS unit, the point of failure in the first attempt. Unfortunately, the unit was lost within one day of attachment. A VHF signal could not be located, and thus the unit was lost. Two attempts were initiated to recapture another beaver and after ten days the traps were removed. In addition, traps were set up along the Lower Snake River to capture a river beaver, but similarly, after 10 days with no capture the attempts were abandoned.

\section{$\uparrow \quad$ LITERATURE CITED}

Barnes, D. M., and A. U. Mallik. 2001. Effects of beaver, Castor canadensis, herbivory on streamside vegetation in a northern Ontario watershed. Canadian Field Naturalist 115(1): 9-21.

Beck, J. L., and D. M. Staley. 2005. Monitoring Protocol for American Beaver (Castor Canadensis): Examples from the Big Horn and Black Hills National Forests, unpublished report, USDA Forest Service, Region 2.

Beier, P., and R. H. Barrett. 1987. Beaver habitat use and impact in Truckee River basin, California. The Journal of Wildlife Management 51:794799.

Belovsky, G. E. 1984. Summer diet optimization by beaver. American Midland Naturalist 111: 209-222.

Bird, B., D. Budrow, D. Hebert, A. Nguyen and J. Roybal. 2013. Assessing beaver habitat on
Federal Lands in New Mexico, WildEarth Guardians Report, New Mexico Department of Environment, Santa Fe, NM.

Bloomquist, C. K., and C. K. Nielsen. 2010. Demography of unexploited beavers in southern Illinois. The Journal of Wildlife Management 74(2): 228-235.

Breck, S. W., K. R. Wilson, and D. C. Andersen. 2001. The demographic response of bank-dwelling beavers to flow regulation: A comparison on the Green and Yampa rivers. Canadian Journal of Zoology 79(11): 1957-1964.

Collins, T.C. 1977. Population Characteristics and Habitat Relationships of Beavers, Castor canadensis, in Northwest Wyoming, Ph.D. Dissertation, University of Wyoming, Laramie, WY.

Cox, D.R., and T.A. Nelson. 2009. Beaver habitat models for use in Illinois streams. Transactions of the Illinois Sate Academy of Science 102(1\&2): 55-64.

Crawford, J. C., Z. Liu, T. A. Nelson, C. K. Nielson, and C. K. Bloomquist. 2009. Genetic population structure within and between beaver (Castor canadensis) populations in Illinois. Journal of Mammalogy 90(2): 373-379.

Donkor, N. T., and J. M. Fryxell. 1999. Impact of beaver foraging on structure of lowland boreal forests of Algonquin Provincial Park, Ontario. Forest Ecology and Management 71:25172526.

Estes, L. D., G. S. Okin, A. G. Mwangi, and H. H. Shugart. 2008. Habitat selection by a rare forest antelope: A multi-scale approach combining field data and imagery from three sensors. Remote Sensing of Environment 112(5): 2033-2050.

František, J., and V. Kostkan. 2009. Compositional analysis and GPS/GIS for study of habitat selection by the European beaver, Castor fiber, in the middle reaches of the Morava River. Folia Zool: 58(1): 76-86.

Fryxell, J. M., and C. M. Doucet. 1993. Diet choice and the functional response of beavers. Ecology 74(5): 1298-1306.

Fustec, J., T. Lode, D. LeJacques, and J. P. Cormier. 2001. Colonization, riparian habitat selection and home range size in a reintroduced population of European beavers in the Loire. Freshwater Biology 46(10): 1361-1371.

Gallant, D., C. H. Berube, F. Tremblay, and L. Vasseur. 2004. An extensive study of the foraging ecology of beavers (Castor canadensis) in relation to habitat quality. Canadian Journal of Zoology 82(6): 922-933. 
Graf, W. L. 2000. Locational probability for a dammed, urbanizing stream: Salt River, Arizona, USA. Environmental Management 25(3): 321-335.

Gribb, W.J., and H. Harlow. 2006. The use of geoinformatics in the construction of a beaver (Castor canadensis) habitat suitability model for Grand Teton National Park, Wyoming. Final Report, UW-NPS Research Station, University of Wyoming.

Gribb, W.J., and H. Harlow. 2011. Determination of central foraging strategies and location of beaver (Castor canadensis) in Grand Teton National Park. Final Report, UW-NPS Research Station, University of Wyoming.

Hartman, G. 1996. Habitat selection by European beaver (Castor fiber) colonizing a boreal landscape. Journal of Zoology 240(2): 317325.

Howard, R. J., and J. S. Larson. 1985. A stream habitat classification system for beaver. The Journal of Wildlife Management 49: 19-25.

Jenkins, S. H. 1980. A size-distance relation in food selection by beavers. Ecology 61: 740-746.

Johnson, D.H. 2001. Validating and evaluating models. Pages 105-119 In: Modeling in Natural Resource Management. T. M. Schenk and A. B. Franklin (eds.) Island Press, Covelo, CA.

Mangel, M., O. Fiksen, and J. Giske. 2001. Theoretical and statistical models in natural resource management and research. Pages 57-72 In: Modeling in Natural Resource Management. T. M. Schenk and A. B. Franklin (eds.) Island Press, Covelo, CA.

Maringer, A., and L. Slotta-Bachmayr. 2006. A GISbased habitat-suitability model as a tool for the management of beavers, Castor fiber. Acta theriologica 51(4): 373-382.

McGinley, M. A., and T. G. Whitham. 1985. Central place foraging by beavers (Castor canadensis): A test of foraging predictions and the impact of selective feeding on the growth form of cottonwoods (Populus fremontii). Oecologia 66(4): 558-562.

McNew, L. B., and A. Woolf. 2005. Dispersal and survival of juvenile beavers (Castor canadensis) in southern Illinois. The American Midland Naturalist 154(1): 217-228.

McNew, L. B., C. K. Nielson, and C. K. Bloomquist. 2007. Use of snares to live-capture beavers. Human-Wildlife Conflicts 1:106-111.

Muller-Schwarze, D., and L. Sun. 2003. The Beaver: Natural History of a Wetlands Engineer. Comstock Publ. Association, Ithaca, NY

Morgan, L. 1868. American Beaver: A Classic of Natural History and Ecology. J.B. Lippincott and Co., Philadelphia, PA
Naiman, R. J., J. M. Melillo, and J. E. Hobbie. 1986. Ecosystem alteration of boreal forest streams by beaver (Castor canadensis). Ecology 67(5): 1254-1269.

Naiman, R. J., C. A. Johnston, and J. C. Kelley. 1988. Alteration of North American streams by beaver. BioScience 38(11): 753-762.

Ohmart, R. D., and B. W. Anderson. 1986. Riparian habitat. Pages 169-199 In: Inventory and Monitoring of Wildlife Habitat. A. Y. Cooperrider, R. J. Boyd, and H. R. Stuart (eds.), Bureau of Land Management, US Printing Office.

Pearce, J., and S. Ferrier. 2000. Evaluating the predictive performance of habitat models developed using logistic regression. Ecological Modelling 133(3): 225-245.

Pinkowski, B. 1983. Foraging behavior of beavers (Castor canadensis) in North Dakota. Journal of Mammalogy 64: 312-314.

Raffel, T. R., N. Smith, C. Cortright, and A. J. Gatz. 2009. Central place foraging by beavers (Castor canadensis) in a complex lake habitat. American Midland Naturalist 162(1): 62-73.

Rothmeyer, S. W., M. C. McKinstry, and S.H. Anderson. 2002. Tail attachment of modified ear-tag radio transmitters on beavers. Wildlife Society Bulletin 30: 425-429.

Seavy, N. E., T. Gardali, G. Golet, F. Griggs, C. Howell, R. Kelsey, S. Small, J. Viers, and J. F. Weigand. 2009. Why climate change makes riparian restoration more important than ever: Recommendations for practice and research. Ecological Restoration 27(3): 330-338.

Shenk, T. M., and A. B. Franklin. 2001. Modeling in natural resource management: An introduction. Pages 1-11 In: Modeling in Natural Resource Management, T. M. Shenk and A. B. Franklin (eds.) Island Press, Washington DC.

Slough, B. G., and R. Sadleir. 1977. A land capability classification system for beaver (Castor canadensis). Canadian Journal of Zoology 55(8): 1324-1335.

Sun, L., D. Müller-Schwarze, and B. A. Schulte. 2000. Dispersal pattern and effective population size of the beaver. Canadian Journal of Zoology 78(3): 393-398.

Suzuki, N., and W. C. McComb. 1998. Habitat classification models for beaver (Castor canadensis) in the streams of the central Oregon Coast Range. Northwest Science 72(2): 102-110.

Wright, J. P., and C.G. Jones. 2006. The concept of organisms as ecosystem engineers ten years on: Progress, limitations and challenges. BioScience 56(3): 203-209. 